\title{
PENGEMBANGAN WILAYAH BERBASIS POTENSI UNGGULAN DI KABUPATEN MANGGARAI TIMUR PROVINSI NTT SEBAGAI DAERAH OTONOM BARU
}

\author{
Regional Development Based on Dominant Potential in East Manggarai \\ Regency, East Nusa Tenggara Province as a New Autonomous Region
}

\author{
Maria Fransiska Darlen ${ }^{1}$, Setia Hadi², M Ardiansyah²
}

Diterima: 22 Desember 2014

Disetujui: 30 Januari 2015

\begin{abstract}
Abstrak: Kabupaten Manggarai Timur merupakan sebuah daerah otonom baru, hasil pemekaran dari Kabupaten Manggarai di wilayah Provinsi Nusa Tenggara Timur.Sebagai sebuah Kabupaten baru, daerah ini perlu dikembangkan berdasarkan potensi-potensi unggulan daerah sehingga Pemerintah Daerah lebih leluasa untuk merancang strategi pengembangan wilayah yang tepat dan menciptakan iklim investasi yang kondusif untuk menarik minat para investor ke daerah ini.Penelitian ini bertujuanmengidentifikasi potensi-potensi unggulan yang dapat dikembangkan dan memberikan nilai ekonomi lebih, mengevaluasi penggunaan lahan eksisting berdasarkan kemampuan lahandan merumuskan strategi pengembangan wilayah Kabupaten Manggarai Timur. Metode yang digunakan adalah analisis input-output dipadu dengan analisis LQ dan SSA untuk mengetahui sektor unggulan dan komoditas unggulan, interpretasi citra dan analisis kemampuan lahan serta analisis SWOT untuk merumuskan strategi pengembangan wilayah. Hasil penelitian menunjukkan bahwa sektor-sektor unggulan di daerah ini terdiri atas sektor tanaman bahan makanan, sektor industri pengolahan nonmigas dan sektor perdagangan. Berdasarkan kemampuan lahan, masih banyak kawasan yang tidak sesuai peruntukannya seperti pengelolaan usahatani di lahan-lahan ekstrim. Dengan demikian, perlu strategi yang tepat dalam mengelola wilayah lewat kebijakan-kebijakan Pemerintah yang kondusif bagi perkembangan sektor-sektor unggulan tersebut.
\end{abstract}

Kata kunci: sektor unggulan, analisis input output, kemampuan lahan, SWOT

\begin{abstract}
East Manggarai Regency is a new autonomous region of the division of Manggarai Regency in East Nusa Tenggara Province. As a new district, the area must be developed based on the dominant potentials in the region so that the regional government is more flexibel to design appropriate regional development strategy and create a conducive investment climate to attract investors to the area. The purpose of research is to identify potential sectors that can be developed and provide more economic value, evaluating existing landuse based on land capability and formulate East Manggarai District development strategies. The method used is the inputoutput analysis combined with analysis of LQ, LI, SI and SSA to determine the dominant sectors and leading commodity, image interpretation and analysis of land capability and SWOT analysis to formulate a regional development strategy. The results showed that the leading sectors in East Manggarai district consists ofthe food crops, the manufacturing sector and the non-oil sectorand the trade sector. Based on the ability of the land, there are many areas that are not their designation as the management of extreme farm lands. Thus, it needs the appropriate strategy in the management of the territory through conducive government policies to the development of the leading sectors.
\end{abstract}

Keywords: dominant sector, input output analysis, land capability, SWOT

\footnotetext{
${ }^{1}$ Program Magister Ilmu Perencanaan Wilayah, Fakultas Pertanian, IPB

${ }^{2}$ Program Studi Ilmu Perencanaan Wilayah, Fakultas Pertanian, IPB
} 


\section{Pendahuluan}

Proses pembangunan di Indonesia telah berjalan kurang lebih 69 tahun, sungguhpun telah terjadi banyak perubahan, namun belum menyentuh seluruh wilayah Indonesia terutama kawasan timur yang belum mengalami perkembangan signifikan. Pembangunan daerah merupakan bagian yang tidak terpisahkan dari proses pembangunan nasional secara keseluruhan, yang dilaksanakan untuk meningkatkan kesejahteraan dan kemakmuran yang adil dan merata bagi seluruh masyarakat. Era reformasi di Indonesia yang dimulai sejak tahun 1998 telah merubah paradigma pemerintahan yang sentralistik menjadi desentralistik. Pembentukan daerah otonomi baru di era reformasi merupakan konsekuensi logis dari penerapan kebijakan desentralisasi politik oleh pemerintah pusat di daerah.

Pembentukan daerah otonomi baru bukanlah fenomena baru karena kebijakan inisebenarnya telah berlangsung secara aktif mulai tahun 1950-an. Paska diterbitkannya UndangUndang Nomor 22 Tahun 1999 yang direvisi dengan Undang-Undang Nomor 32 Tahun 2004 tentang Pemerintahan Daerah, telah menyulut keinginan daerah untuk merealisasikan pemekaran wilayahnya, terlebih ketika dikaitkan dengan sejarah represif orde baru yang hanya memfokuskan pertumbuhan beberapa daerah. Undang-Undang Nomor 32 Tahun 2004 menjelaskan bahwa pembangunan daerah sebagai bagian integral dari pembangunan nasional dilaksanakan oleh pemerintah daerah berdasarkan prinsip otonomi dan pengaturan sumber daya yang diarahkan untuk mempercepat terwujudnya kesejahteraan masyarakat melalui peningkatan pelayanan, pemberdayaan dan partisipasi masyarakat serta peningkatan daya saing daerah (Pemerintah Republik Indonesia 2004).

Kebijakan ini telah memberikan keleluasaan bagi daerah untuk menyelenggarakan pemerintahannya di berbagai bidang kehidupan dengan harapan dapat mengoptimalkan berbagai potensi daerah yang belum tergarap baik potensi alam maupun potensi manusia, memutuskan mata rantai pelayanan yang sebelumnya terpusat di satu wilayah, memunculkan pusat-pusat pertumbuhan ekonomi baru dan memicu motivasi masyarakat untuk berpartisipasi aktif dalam pembangunan guna meningkatkan kesejahteraannya. Implikasi yang paling strategis dalam hubungan ini adalah Pemerintah Daerah dituntut untuk mampu membiayai sendiri pembangunan daerahnya.

Oleh sebab itu, dalam proses pembangunan daerah perlu diterapkan pengembangan wilayah berbasis potensi unggulan daerah guna membiayai dan mengefektifkan pelaksanaan pembangunan daerah sehingga memiliki daya saing dalam persaingan nasional maupun global. Proses pengembangan wilayah tidak dapat dilakukan serentak pada semua sektor perekonomian, namun diprioritaskan pada pengembangan sektor ekonomi yang memiliki potensi perkembangancukup besar. Sektor ini diharapkan dapat berkembang dan mendorong sektor ekonomi yang terkait untuk berkembang sehingga tercipta keterkaitan sektoral.Berbagai hal tersebut telahmendorong penulis untuk mengkaji pengembangan wilayah berbasis potensi daerah di Kabupaten Manggarai Timursebagai kabupaten daerah otonom baru yang terletak di bagian barat Provinsi Nusa Tenggara Timur.

Kabupaten Manggarai Timur dibentuk berdasarkan Undang-Undang Nomor 36 Tahun 2007 dan diresmikan pada tanggal 23 November 2007.Sebagai kabupaten hasil pemekaran, tentunya Kabupaten Manggarai Timur memiliki berbagai hambatan dan kendala yang dihadapi terutama dari hasil intervensi pembangunan Kabupaten indukpada era sebelum pemekaran. Pembangunan yang ada telah menghasilkan beberapa kemajuan untuk meningkatkan kesejahteraan dan kemakmuran masyarakat, namun masih saja terdapat berbagai hambatan, tantangan dan masalah berkelanjutan yang tetap menjadi beban pembangunan daerah masa kini. Pola pembangunan yang diterapkan selama ini belum mampu menghasilkan pemerataan kesejahteraan masyarakat baik dalam hal ekonomi maupun akses mendapatkan pelayanan publik yang berkualitas, terutama di tengah hambatan topografis yang ada. Dengan mengetahui potensi unggulan, Pemerintah Daerah akan lebih leluasa untuk merancang strategi pengembangan wilayahnya serta menciptakan iklim investasi yang kondusif untuk menarik minat para investor 
ke daerah.Adapun tujuandari penelitian ini yaitu 1) mengidentifikasi potensi unggulan yang dapat dikembangkan dan memberikan nilai ekonomi lebih bagi Kabupaten Manggarai Timur; 2) mengevaluasi kemampuan lahan berdasarkan penggunaan lahan eksisting di Kabupaten Manggarai Timur; 3) merumuskanstrategi pengembangan wilayah Kabupaten Manggarai Timur.

\section{Metode}

\section{Lokasi dan Waktu Penelitian}

Penelitian dilakukan di wilayah Kabupaten Manggarai Timur, Provinsi NTT yang meliputi enam kecamatan yaitu Kecamatan Borong, Kota Komba, Elar, Sambi Rampas, Lamba Leda dan Poco Ranaka. Daerah ini terletak antara08014'- $09^{\circ} 00$ Lintang Selatan dan 120020'-120055' Bujur Timur dengan batas wilayah geografis meliputi: 1) sebelah utara berbatasan dengan Laut Flores; 2) sebelah selatan berbatasan dengan Laut Sawu; 3) sebelah timur berbatasan dengan Kabupaten Ngada; 4) sebelah barat berbatasan dengan Kabupaten Manggarai. Penelitian ini berlangsung dari bulan Aprilhingga bulanNovember 2014.

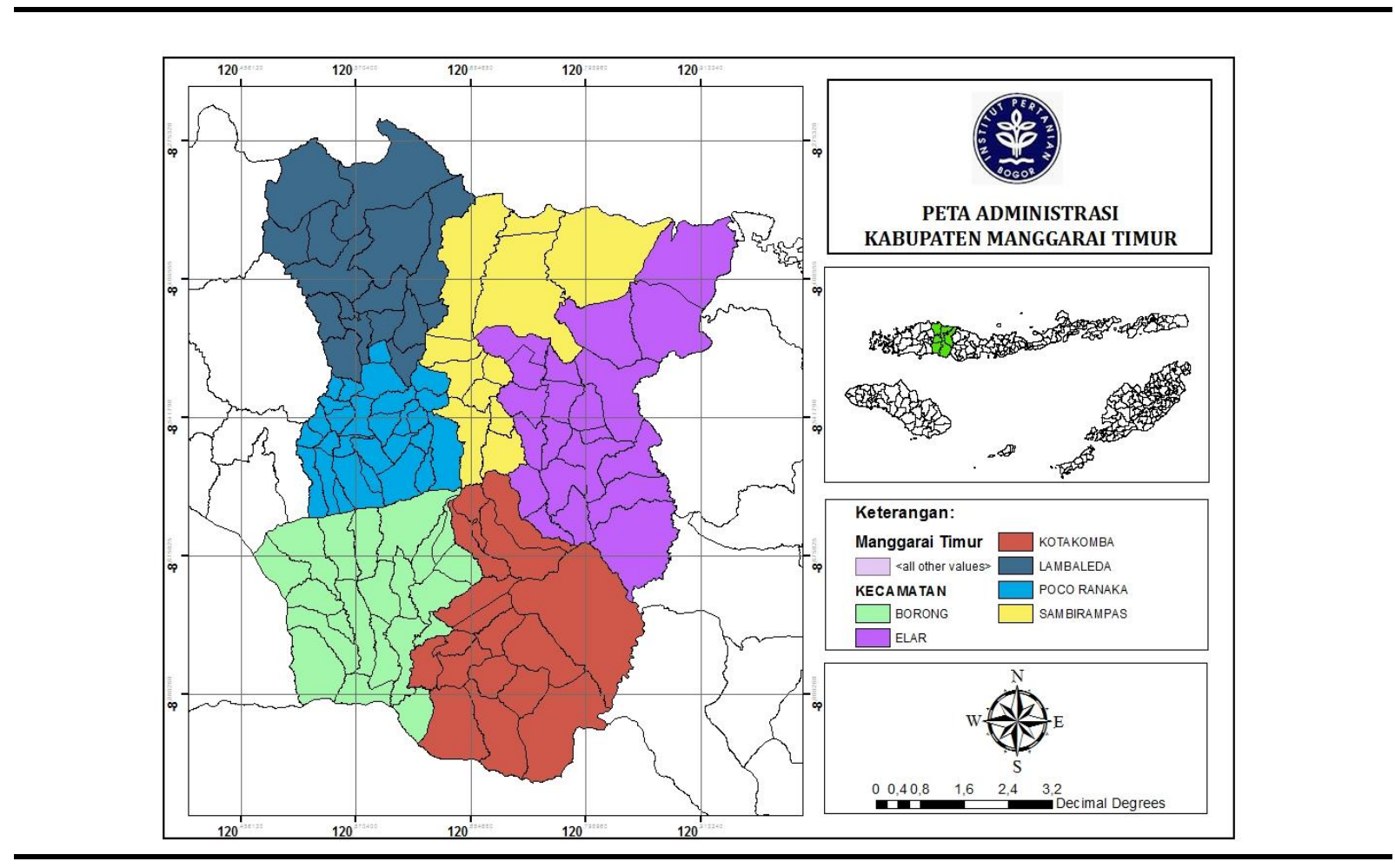

Gambar 1. Peta Administrasi Kabupaten Manggarai Timur Tahun 2013

\section{Jenis dan Sumber Data}

Data yang digunakan berupa data primer dan data sekunder.Data primer diperoleh dari hasil pengamatan di lapangan dan wawancara dengan narasumber meliputi pejabat instansi dan tokoh masyarakat.Data sekunder meliputi citra Kabupaten Manggarai Timur (2013); data penggunaan lahan (landuse) Kabupaten Manggarai Timur (2012); buku Kabupaten Manggarai Timur dalam angka 2013; potensi desa (Podes) 2012 dan tabel input output Provinsi NTT (2006) serta sumber tertulis lain yang berkaitan dengan permasalahan yang dikaji seperti buku, artikel dan jurnal.Instansi-instansi yang dituju yaitu Badan Informasi Geospasial (BIG) dan Balai Besar 
Sumber Daya Lahan Pertanian (BBSDLP) Bogor, Badan Pusat Statistik Provinsi NTT dan Kabupaten Manggarai Timur serta Badan Perencanaan Pembangunan Daerah (Bappeda) Kabupaten Manggarai Timur. Perangkat lunak (software)yang digunakanmeliputi ArcGIS v.10, Microsoft office (word dan excel) 2010 dan GAMS v.22.2.

\section{Teknik AnalisisData}

Teknik analisis data yang digunakan untuk menjawab tujuan penelitian terdiri dari tiga analisis sebagai berikut.

\section{Identifikasi Potensi Unggulan}

Dalam mengidentifikasi sektor yang menjadi potensi unggulan yang dapat Kabupaten Manggarai Timur digunakan analisisinput output. Data yang digunakan adalah tabel transaksiinput outputProvinsi NTT atas dasar harga produsen tahun 2006 yangmenggambarkan nilai transaksi barang dan jasa antarsektor ekonomi yaituunsur margin perdagangan dan biaya pengangkutan telah dipisahkan sebagai input yang dibeli dari sektor perdagangan dan pengangkutan. Pembaharuan tabel input output Provinsi NTT tahun 2006 menjadi tabel input output Kabupaten Manggarai Timur tahun 2012 menggunakan metode RAS dengan bantuan software GAMS v.22.2. Asumsi yang digunakan yaitu terdapat kemiripan struktur ekonomi antara Kabupaten Manggarai Timur dengan Provinsi NTT sebagai induknya.

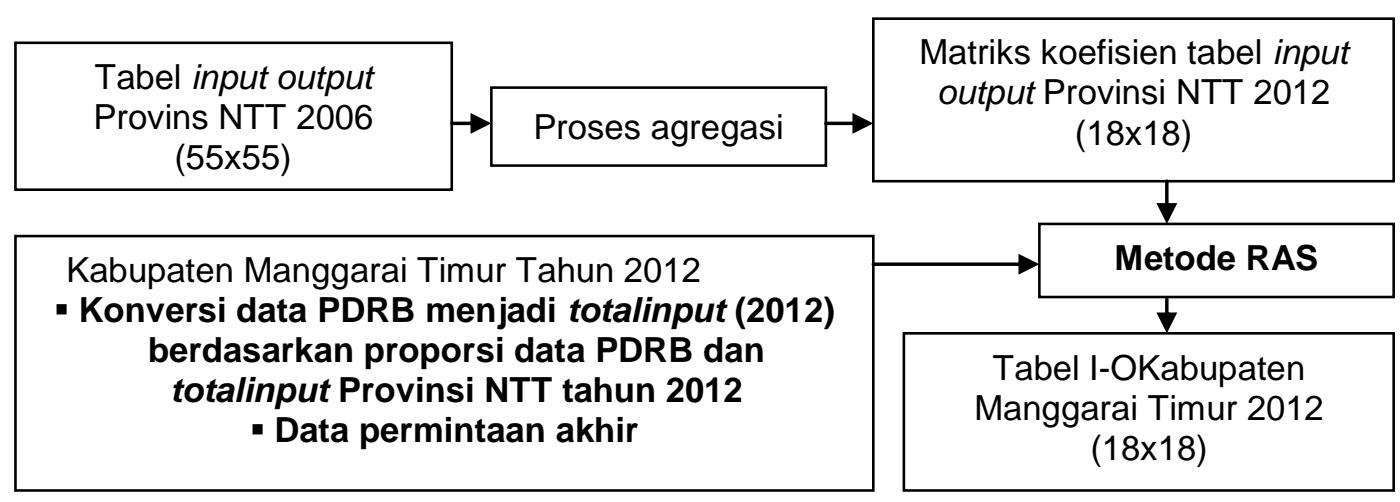

Gambar 2 Tahapan Metode RAS

Tabel 1 Sektor-sektor perekonomian Kabupaten Manggarai Timur tahun 2012

\begin{tabular}{clcl}
\hline $\begin{array}{c}\text { Kode } \\
\text { I-O }\end{array}$ & \multicolumn{1}{c}{ Sektor } & $\begin{array}{c}\text { Kode } \\
\text { I-O }\end{array}$ & Sektor \\
\hline 1 & Tanaman bahan makanan & 10 & Perdagangan \\
2 & Tanaman perkebunan & 11 & Perhotelan \\
3 & Peternakan dan hasil-hasilnya & 12 & Restoran \\
4 & Kehutanan & 13 & Pengangkutan \\
5 & Perikanan & 14 & Komunikasi \\
6 & Pertambangan dan penggalian nonmigas & 15 & Bank dan Lembaga keuangan lain \\
7 & Industri pengolahan nonmigas & 16 & Sewa bangunan \& Jasa perusahaan \\
8 & Listrik dan air bersih & 17 & Jasa Pemerintahan Umum \\
9 & Bangunan & 18 & Jasa Swasta \\
\hline
\end{tabular}

Sumber: BPS Manggarai Timur (2013) 
Secara matematis, persamaan analisis input output (Rustiadi 2009) sebagai berikut.

$$
a_{i j}=\frac{x_{i j}}{X_{j}} \text { atau } x_{i j}=a_{i j} \cdot x_{j}
$$

$\mathrm{a}_{\mathrm{ij}}$ merupakan rasio antara banyaknya output sektor i yang digunakan sebagai input sektor $\mathrm{j}\left(\mathrm{x}_{\mathrm{ij}}\right)$ terhadap total input sektor $\mathrm{j}\left(\mathrm{X}_{\mathrm{j}}\right)$, disebut koefisien input. Beberapa parameter teknis dalam analisis input-output:

1. Kaitan langsung ke belakang (direct backward linkage/ $\mathrm{B}_{\mathrm{j}}$ )

Efek permintaan suatu sektor terhadap perubahan tingkat produksi sektor-sektor yang menyediakan input antara bagi sektor tersebut secara langsung, yaitu dengan menjumlahkan tiap kolom $a_{i j}$ di tiap kolom $\mathrm{j}$.

$$
\mathrm{B}_{\mathrm{j}}=\sum_{\mathrm{i}}^{\mathrm{n}} \mathrm{a}_{\mathrm{ij}}
$$

Untuk melihat perbandingan dengan sektor lain, terdapat ukuran normalized $\mathrm{B}_{\mathrm{j}}^{*}$ yaitu rasio antar kaitan langsung ke belakang sektor $\mathrm{j}$ (direct backward linkage sektor $\mathrm{j}$ ) dengan rata-rata backward linkage sektor-sektor lainnya.

$$
B_{j}^{*}=\frac{B_{j}}{\frac{1}{n} \sum_{j} B_{j}}=\frac{n \cdot B_{j}}{\sum_{j} B_{j}}
$$

Nilai $\mathrm{B}_{\mathrm{i}}^{*}>1$ menunjukkan bahwa sektor $\mathrm{j}$ memiliki pengaruh kuat terhadap pertumbuhan sektor-sektor lain dalam memenuhi derived demand (turunan permintaan) yang ditimbulkan oleh sektor ini.

2. Kaitan langsung ke depan (direct forward linkage/ $\mathrm{F}_{\mathrm{i}}$ )

Banyaknya output suatu sektor yang dipakai oleh sektor-sektor lain

Normalized $\mathrm{F}_{\mathrm{i}}$ atau $\mathrm{F}_{\mathrm{i}}^{*}$ dirumuskan sebagai berikut:

$$
\mathbf{F}_{\mathbf{i}}=\sum_{j}^{\mathbf{n}} \mathbf{a}_{\mathbf{i j}}
$$

$$
\mathbf{F}_{\mathbf{i}}^{*}=\frac{\mathbf{F}_{\mathbf{i}}}{\frac{1}{\mathbf{n}} \sum_{\mathbf{i}} \mathbf{F}_{\mathbf{i}}}=\frac{\mathbf{n} \mathbf{F}_{\mathbf{i}}}{\sum_{\mathbf{i}} \mathbf{F}_{\mathbf{i}}}
$$

3. Kaitan ke belakang langsung dan tidak langsung (indirect backward linkage/BLj) yang menunjukkan pengaruh tidak langsung dari kenaikan permintaan akhir satu unit sektor tertentu (j) yang dapat meningkatkan total output seluruh sektor perekonomian.

$$
\mathbf{B L}_{\mathbf{j}}=\sum_{\mathbf{i}}^{\mathbf{n}} \mathbf{b}_{\mathbf{i j}}
$$

$b_{\mathrm{ij}}$ adalah elemen-elemen matriks $\mathrm{B}$ atau $(\mathrm{I}-\mathrm{A})^{-1}$ yang merupakan invers matriks Leontief. Adapun indeks daya penyebaran (backward power of dispersion $/ \beta_{\mathrm{j}}$ ) menunjukkan kekuatan relatif permintaan akhir suatu sektor dalam mendorong pertumbuhan produksi total seluruh sektor perekonomian.

$$
\beta_{j}=\frac{\sum_{\mathrm{i}} \mathrm{b}_{\mathrm{ij}}}{\frac{1}{\mathrm{n}} \sum_{\mathrm{i}} \sum_{\mathrm{j}} \mathrm{b}_{\mathrm{j}}}=\frac{\mathrm{n} \sum_{\mathrm{i}} \mathrm{b}_{\mathrm{ij}}}{\sum_{\mathrm{i}} \sum_{\mathrm{j}} \mathrm{b}_{\mathrm{j}}}
$$

Jika $\beta_{\mathrm{j}}>1$, secara relatif permintaan akhir sektor $\mathrm{j}$ dalam merangsang pertumbuhan produksi lebih besar dari rata-rata.

4. Kaitan ke depan langsung dan tak langsung/indirect forward linkage $\left(\mathrm{FL}_{\mathrm{i}}\right)$

Peranan suatu sektor (i) dapat memenuhi permintaan akhir dari seluruh sektor perekonomian.

$$
\mathrm{FL}_{\mathrm{i}}=\sum_{\mathrm{j}}^{\mathrm{n}} \mathrm{b}_{\mathrm{ij}}
$$

Bila permintaan akhir tiap sektor perekonomian meningkat 1 unit (permintaan akhir seluruh sektor perekonomian adalah $\mathrm{n}$ unit), sektor i menyumbang pemenuhannya sebesar $\mathrm{FL}_{\mathrm{i}}$. Indeks 
daya kepekaan/forward power of dispersion $\left(\mathrm{a}_{\mathrm{i}}\right)$ menunjukkan sumbangan relatif suatu sektor dalam memenuhi permintaan akhir keseluruhan sektor perekonomian.

$$
\alpha_{i}=\frac{\sum_{j} b_{j}}{\frac{1}{n} \sum_{i} \sum_{j} b_{j}}
$$

Jika $\alpha_{i}>1$, sektor tersebut merupakan salah satu sektor yang strategis karena secara relatif dapat memenuhi permintaan akhir di atas kemampuan rata-rata.

5. Multiplier adalahkoefisien yang menyatakan kelipatan dampak langsung dan tidak langsung dari meningkatnya permintaan akhir suatu sektor sebesar satu unit terhadap aspek-aspek tertentu ekonomi suatu wilayah.

a. Output multiplier adalah dampak meningkatnya permintaan akhir suatu sektor terhadap total output seluruh sektor.

$$
\mathrm{X}=(\mathrm{I}-\mathrm{A})^{-1} \cdot \mathrm{F}^{\mathrm{d}}
$$

b. Income multiplier adalah dampak meningkatnya permintaan akhir suatu sektor terhadap peningkatan pendapatan rumah tangga secara keseluruhan.

$$
\mathrm{V}_{\mathrm{j}}=\mathrm{W}_{\mathrm{j}}+\mathrm{T}_{\mathrm{j}}
$$

$\mathrm{V}_{\mathrm{j}}$ adalah input primer sektor $\mathrm{j}, \mathrm{W}_{\mathrm{j}}$ adalah pendapatan rumah tangga (income) sektor $\mathrm{j}$ dan $\mathrm{T}_{\mathrm{j}}$ adalah pendapatan perusahaan sektor $\mathrm{j}$. Koefisien income $\widehat{w}$ adalah $\widehat{w}=\mathrm{W}_{\mathrm{j}} / \mathrm{X}_{\mathrm{i}}$; sehingga income multiplier $\mathrm{W}=\widehat{w} \mathrm{x}$, di mana $\mathrm{W}$ adalah matriks income, $\widehat{w}$ adalah matriks diagonal koefisien income dan $\mathrm{X}$ adalah matriks output, $\mathrm{X}=(\mathrm{I}-\mathrm{A})^{-1} \cdot \mathrm{F}^{\mathrm{d}}$

c Total value added multiplier atau PDRB multiplier adalah dampak meningkatnya permintaan akhir suatu sektor terhadap peningkatan PDRB.

$$
\mathrm{V}=\hat{v} \mathrm{X}
$$

$\mathrm{V}$ adalah matriks NTB, vadalah matriks diagonal koefisien NTB dan X adalah matriks output, $\mathrm{X}=(\mathrm{I}-\mathrm{A})^{-1} \cdot \mathrm{F}^{\mathrm{d}}$

\section{Analisis LQ dan SSA}

Selain analisis input-output, juga digunakan analisis Location Quotient (LQ) dan Shift Share Analysis (SSA) untuk mengidentifikasi komoditas unggulan pertanian di Kabupaten Manggarai Timur. Analisis LQ digunakan untuk mengetahui pemusatan suatu komoditi di suatu wilayah dalam cakupan wilayah agregat yang lebih luas (keunggulan komparatif), sedangkan SSA digunakan untuk melihat tingkat keunggulan kompetitif (competitiveness) suatu wilayah dalam cakupan wilayah agregat yang lebih luas, berdasarkan komoditi lokal wilayah tersebut.

Keterangan :

$$
L Q_{I J}=\frac{X_{I J} / X_{I}}{X_{. J} / X_{.}}
$$

$\mathrm{X}_{\mathrm{ij}}=$ Nilai produksi komoditi $\mathrm{j}$ di wilayah $\mathrm{i}$

$\mathrm{X}_{\mathrm{i}}=$ Nilai total produksi komoditi $\mathrm{j}$ di wilayah $\mathrm{i}$

$\mathrm{X}_{\mathrm{j}} \quad=$ Nilai produksi komoditi $\mathrm{j}$ pada wilayah agregat

X.. = Nilai total produksi komoditi di wilayah agregat

Interpretasi nilai LQ:

0 : aktifitas tidak berkembang

1 : perkembangan komoditi sama dengan rataan seluruh unit wilayah

$<1$ : perkembangan komoditi di bawah rataanseluruh unit wilayah (bukan unggulan)

$>1$ : perkembangan komoditi lebih tinggi darirataan seluruh unit wilayahatau indikasi adanya pemusatan aktifitasdi unit wilayah tersebut (unggulan)

$$
S S A=\left(\frac{X_{. \alpha(1)}}{X_{.(t(0)}}-1\right)+\left(\frac{X_{i(t 1)}}{X_{i(t 0)}}-\frac{X_{.(t 1)}}{X_{.(t 0)}}\right)+\left(\frac{X_{i j(t)}}{X_{i j(t)}}-\frac{X_{i(t)}}{X_{i(t 0)}}\right)^{2}
$$

a 
Keterangan:

$\mathrm{a}=$ komponen regional share(kontribusi pergeseran total seluruh komoditi di total wilayah agregat yang lebih luas)

$\mathrm{b}=$ komponen proportional shift(pergeseran total komoditi tertentu di wilayah agregat yang lebih luas)

$\mathrm{c}=$ komponen differential shift(pergeseran suatu komoditi unggulan di suatu wilayah tertentu)

$\mathrm{X} . .=$ total produksi seluruh komoditi secara agregat wilayah

$\mathrm{X} . \mathrm{i}=$ jumlahproduksi komoditi tertentu secara agregat

$\mathrm{Xij}=$ jumlah produksi komoditi tertentu dalam unit wilayah tertentu

$\mathrm{t} 1=$ titik tahun akhir

t0 = titik tahun awal

\section{Evaluasi Kemampuan Lahan Berdasarkan Tutupan/Penggunaan Lahan Eksisting}

Analisis yang digunakan meliputi dua hal yaitu menelaah kondisi tutupan/penggunaan lahan eksisting dan melakukan kajian kemampuan lahan di Kabupaten Manggarai Timur.

1) Interpretasi citra dengan mengidentifikasi jenis tutupan/penggunaan lahan di Kabupaten Manggarai Timur, sehingga diperoleh peta tutupan/penggunaan lahan.Interpretasi dilakukan secara visual dengan mengacu pada klasifikasi jenis tutupan/penggunaan lahan tahun 2012.

2) Analisis kemampuan lahan:overlay beberapa peta tematik meliputi lereng, kedalaman tanah, tekstur tanah, drainase, batuan dan salinitas sehingga diperoleh peta kelas kemampuan lahan.

Selanjutnya, peta penggunaan lahan dan peta kelas kemampuan lahan dioverlay untuk memperoleh peta kesesuaian antara tutupan/penggunaan lahan dengan kemampuan lahan.

\section{Perumusan Strategi Pengembangan Wilayah}

Dalam merumuskanstrategi pengembangan wilayah Kabupaten Manggarai Timur berbasis potensi unggulan wilayah digunakan analisis SWOTdengan terlebih dahulu mengidentifikasi kekuatan (strength), kelemahan (weakness), peluang (opportunity) dan tantangan (threat).

\section{Hasil Dan Pembahasan}

\section{Sektor Unggulan}

Pengembangan sektor unggulan memiliki relevansi kuat dengan pengembangan wilayah. Sektor tersebut akan berkembang dan mendorong sektor lain yang terkait sehingga membentuk sistem keterkaitan antarsektor. Penetapan sektor unggulan bertujuan mempercepat laju pertumbuhan ekonomi sehingga tercipta stabilitas ekonomi yang sehat dan dinamis, menciptakan kemakmuran dan kesejahteraan yang dinikmati oleh masyarakat di daerah, meningkatkan kontribusi PDRB dan menciptakan lapangan kerja.

Tabel 2 Struktur tabel input-output Kabupaten Manggarai Timur tahun 2012

\begin{tabular}{|c|c|c|c|}
\hline No & Uraian & Jumlah (juta rupiah) & Persentase (\%) \\
\hline & Struktur input & 1553581.12 & \\
\hline 1 & Jumlah input antara & 311410.69 & \\
\hline 2 & Jumlah impor & 99385.71 & \\
\hline \multirow[t]{6}{*}{3} & Jumlah input primer/nilai tambah bruto & 1142784.73 & 100.00 \\
\hline & a. upah dan gaji & 378294.85 & 33.10 \\
\hline & b. surplus usaha & 710915.28 & 62.21 \\
\hline & c. penyusutan & 35007.09 & 3.06 \\
\hline & d. pajak tak langsung & 18567.51 & 1.62 \\
\hline & Struktur output & 1676108.22 & 100.00 \\
\hline 1 & Jumlah output antara & 311410.69 & 18.58 \\
\hline 2 & Jumlah output akhir & 1364697.53 & 81.42 \\
\hline
\end{tabular}

Sumber: Hasil RAS tabel input-putput Provinsi NTT (2006), 2014 
Berdasarkan komposisi struktur I-O dalam Tabel 2, Kabupaten Manggarai Timur mengalami potensi kebocoran wilayah karena besaran persentase surplus usaha jauh melebihi upah dan gaji. Manfaat yang dirasakan langsung oleh masyarakat sangat rendah dibandingkan yang dinikmati oleh pengusaha/investor. Komponen surplus usaha yang lebih besar dibandingkan upah dan gaji masih tetap baik bila keuntungan tersebut diinvestasikan lagi di daerah. Hal ini dimungkinkan terutama bila investor merupakan pengusaha lokal dibandingkan investor dari luar daerah. Oleh sebab itu investasi yang baik selain dilakukan dengan memanfaatkan sumber daya lokal, juga harus memberikan pengaruh positif bagi wilayah secara keseluruhan serta mampu mengurangi terjadinya kebocoran wilayah.

Kecilnyapermintaan antara dibandingkan permintaan akhir menggambarkan rendahnyapermintaan yang terjadi antarsektor ekonomi. Semakin kecil persentase permintaan antarwilayah, semakin kecil pula keterkaitan ekonomi domestik dalam melakukan proses produksi. Ini menjelaskan bahwa output yang ada cenderung digunakan untuk konsumsi secara langsung baik konsumsi rumah tangga maupun belanja pemerintah daripada ditransaksikan antarsektor. Tinggi/rendahnya stuktur output dalam transaksi input-output mengindikasikan tinggi/rendahnya tingkat transaksi dalam daerah, juga tingkat permintaan domestik dan ekspor.

Berdasarkan Tabel 3, sektor tanaman bahan makanan memberikan kontribusi terbesar bagi pembentukan total output( $(31.76 \%)$ diikuti oleh sektor jasa pemerintahan umum (12.07\%) dan sektor perdagangan (11.67 \%). Ketiga sektor ini menghasilkan barang dan jasa terbanyak yang digunakan oleh sektor-sektor lain dalam kegiatan produksinya.

Tabel 3 Total outputBerdasarkan Tabel Input-OutputTahun 2012

\begin{tabular}{clrr}
\hline \multirow{2}{*}{ No Sektor } & & \multicolumn{2}{c}{ Total output } \\
\cline { 3 - 4 } & & Tanaman bahan makanan & Jumlah (juta rupiah) \\
2 & Jasa Pemerintahan umum & 532309.44 & 31.76 \\
3 & Perdagangan & 202334.77 & 12.07 \\
4 & Tanaman perkebunan & 195635.75 & 11.67 \\
5 & Bangunan & 190535.91 & 11.37 \\
6 & Peternakan dan hasil-hasilnya & 181465.14 & 10.83 \\
7 & Jasa swasta & 158173.81 & 9.44 \\
8 & Pertambangan dan penggalian nonmigas & 72407.94 & 4.32 \\
9 & Perikanan & 37180.14 & 2.22 \\
10 & Industri pengolahan nonmigas & 30817.54 & 1.84 \\
11 & Pengangkutan & 24483,47 & 1.46 \\
12 & Sewa bangunan dan jasa perusahaan & 19572.44 & 1.17 \\
13 & Bank dan lembaga keuangan lain & 18900.45 & 1.13 \\
14 & Kehutanan & 7882.12 & 0.47 \\
15 & Restoran & 1324.84 & 0.08 \\
16 & Listrik dan air bersih & 1048.76 & 0.06 \\
17 & Perhotelan & 1039.15 & 0.06 \\
18 & Komunikasi & 731.34 & 0.04 \\
\hline
\end{tabular}

Sumber: Hasil RAS tabel input-putput Provinsi NTT 2014

Terjadinya interaksi ekonomi yang kuat, menyeluruh dan berkelanjutan di antara semua sektor ekonomi menjadi kunci keberhasilan pembangunan ekonomi. Pertumbuhan ekonomi yang tinggi dan pemerataan pendapatan per kapita merupakan tolak ukur utama bagi pembangunan suatu daerah. Tingkat perkembangan dan keberhasilan pembangunan suatu wilayah identik dengan tingkat pertumbuhan ekonomi yang direpresentasikan dengan peningkatan produk domestik bruto/PDB (Rustiadi et al. 2009).Selain menjadi penyedia input bagi sektor lain, sektor tanaman bahan makanan (37.18 \%) dan sektor perdagangan (14.52\%) juga berkontribusi utama dalam pembentukan PDRB Kabupaten Manggarai Timur selain sektor tanaman perkebunan $(12.45 \%)$. 
Tabel 4 PDRB Kabupaten Manggarai Timur tahun 2012

\begin{tabular}{|c|c|c|c|}
\hline \multirow{2}{*}{ No } & \multirow{2}{*}{ Sektor } & \multicolumn{2}{|l|}{ PDRB } \\
\hline & & Jumlah (juta rupiah) & $\%$ \\
\hline 1 & Tanaman bahan makanan & 424880.86 & 37.18 \\
\hline 2 & Tanaman perkebunan & 142280.76 & 12.45 \\
\hline 3 & Peternakan dan hasil-hasilnya & 95592.91 & 8.36 \\
\hline 4 & Kehutanan & 1015.90 & 0.09 \\
\hline 5 & Perikanan & 22632.20 & 1.98 \\
\hline 6 & Pertambangan dan penggalian nonmigas & 24812.66 & 2.17 \\
\hline 7 & Industri pengolahan & 6975.99 & 0.61 \\
\hline 8 & Listrik dan air bersih & 491.49 & 0.04 \\
\hline 9 & Bangunan & 71276.30 & 6.24 \\
\hline 10 & Perdagangan & 165930.62 & 14.52 \\
\hline 11 & Perhotelan & 148.57 & 0.01 \\
\hline 12 & Restoran & 233.95 & 0.02 \\
\hline 13 & Pengangkutan & 11055.06 & 0.97 \\
\hline 14 & Komunikasi & 138.43 & 0.01 \\
\hline 15 & Bank dan lembaga keuangan lainnya & 4997.41 & 0.44 \\
\hline 16 & Sewa bangunan dan jasa perusahaan & 12375.67 & 1.08 \\
\hline 17 & Jasa pemerintahan umum & 125660.48 & 11.00 \\
\hline \multirow[t]{2}{*}{18} & Jasa swasta & 32285.47 & 2.83 \\
\hline & Total PDRB & 1142784.73 & 100.00 \\
\hline
\end{tabular}

Sumber: BPS Kabupaten Manggarai Timur 2014

Pengertian kontribusi dalam perekonomian berbeda dengan efek sebar yang diberikan oleh suatu sektor. Kontribusi terhadap perekonomian berarti efek yang diperhatikan hanya sebatas pada efek langsung saja (kontribusi PDRB). Hal yang lebih penting dilihat yaitu bagaimana sektor tersebut mampu menggerakkan roda perekonomian wilayah serta dapat memberikan efek lanjut pada aktivitas pembangunan sektor lain baik langsung maupun tidak langsung.

Tabel 5 Keterkaitan Dan Efek Pengganda (Multiplier Effect)Sektor Ekonomi Kabupaten Manggarai Timur

\begin{tabular}{|c|c|c|c|c|c|c|c|c|c|c|c|}
\hline \multirow{2}{*}{ Sektor } & \multicolumn{8}{|c|}{ Keterkaitan antarsektor } & \multicolumn{3}{|c|}{ Multiplier effect } \\
\hline & $B_{j}$ & $\mathrm{~B}_{\mathrm{j}}^{*}$ & $\mathrm{~F}_{\mathrm{i}}$ & $\mathrm{F}_{\mathrm{i}}^{*}$ & $\mathrm{BLj}$ & $\beta_{j}$ & $\mathrm{FL}_{\mathrm{i}}$ & $\alpha_{i}$ & $\mathrm{OM}$ & IM & VM \\
\hline Tanaman bahan makanan & 0.11 & 0.39 & 0.84 & 2.97 & 1.13 & 0.82 & 2.13 & 1.54 & 1.10 & 4.98 & 1.12 \\
\hline Tanaman perkebunan & 0.15 & 0.54 & 0.12 & 0.42 & 1.19 & 0.86 & 1.14 & 0.83 & 1.18 & 5.52 & 1.16 \\
\hline Peternakan dan hasilnya & 0.20 & 0.72 & 0.29 & 1.01 & 1.24 & 0.90 & 1.34 & 0.97 & 1.47 & 5.60 & 1.29 \\
\hline Kehutanan & 0.13 & 0.46 & 0.01 & 0.02 & 1.19 & 0.86 & 1.01 & 0.73 & 21.18 & 5.25 & 1.12 \\
\hline Perikanan & 0.10 & 0.36 & 0.10 & 0.37 & 1.12 & 0.81 & 1.11 & 0.81 & 1.45 & 5.09 & 1.12 \\
\hline $\begin{array}{l}\text { Pertambangan dan penggalian } \\
\text { nonmigas }\end{array}$ & 0.28 & 0.98 & 0.10 & 0.36 & 1.40 & 1.02 & 1.24 & 0.90 & 2.19 & 6.02 & 1.32 \\
\hline Industri pengolahan nonmigas & 0.58 & 2.05 & 0.17 & 0.59 & 1.67 & 1.21 & 1.23 & 0.89 & 11.98 & 10.07 & 2.89 \\
\hline Listrik dan air bersih & 0.44 & 1.57 & 0.02 & 0.09 & 1.65 & 1.20 & 1.03 & 0.75 & 81.28 & 9.79 & 1.72 \\
\hline Bangunan & 0.37 & 1.32 & 1.10 & 3.91 & 1.51 & 1.09 & 2.42 & 1.75 & 1.34 & 7.05 & 1.81 \\
\hline Perdagangan & 0.06 & 0.21 & 0.58 & 2.07 & 1.09 & 0.79 & 1.86 & 1.34 & 1.05 & 4.84 & 1.05 \\
\hline Perhotelan & 0.25 & 0.90 & 0.01 & 0.02 & 1.31 & 0.95 & 1.01 & 0.73 & 105.04 & 8.60 & 2.13 \\
\hline Restoran & 0.37 & 1.32 & 0.01 & 0.03 & 1.46 & 1.06 & 1.01 & 0.73 & 101.49 & 9.29 & 2.48 \\
\hline Pengangkutan & 0.31 & 1.10 & 0.25 & 0.88 & 1.45 & 1.05 & 1.37 & 0.99 & 4.74 & 9.37 & 1.45 \\
\hline Komunikasi & 0.43 & 1.54 & 0.03 & 0.12 & 1.65 & 1.20 & 1.04 & 0.75 & 382.48 & 7.48 & 1.64 \\
\hline Bank dan lembaga keuangan lain & 0.31 & 1.12 & 0.19 & 0.66 & 1.46 & 1.06 & 1.25 & 0.90 & 8.44 & 7.12 & 1.42 \\
\hline $\begin{array}{l}\text { Sewa bangunan dan jasa } \\
\text { perusahaan }\end{array}$ & 0.26 & 0.94 & 0.23 & 0.83 & 1.39 & 1.01 & 1.28 & 0.93 & 4.15 & 8.09 & 1.31 \\
\hline Pemerintahan umum & 0.31 & 1.11 & 0.54 & 1.91 & 1.45 & 1.05 & 1.72 & 1.25 & 1.35 & 5.43 & 1.40 \\
\hline Jasa swasta & 0.39 & 1.38 & 0.49 & 1.74 & 1.50 & 1.09 & 1.68 & 1.22 & 2.67 & 6.31 & 1.76 \\
\hline
\end{tabular}

Sumber: Hasil RAS tabel input-putput Provinsi NTT 2014

Keterangan:

$\mathrm{B}_{\mathrm{j}}=$ kaitan langsung ke belakang/ direct backward linkages

$\mathrm{B}_{\mathrm{j}}{ }^{*}=$ rasio antara $\mathrm{B}_{\mathrm{j}}$ dengan rata-rata kaitan langsung ke belakang sektor-sektor lainnya

$\mathrm{F}_{\mathrm{i}} \quad=$ kaitan langsung ke depan/indirect forward linkages

$\mathrm{F}_{\mathrm{i}}{ }^{*}=$ rasio antara $\mathrm{F}_{\mathrm{i}}$ dengan dengan rata-rata kaitan langsung ke depan sektor-sektor lainnya 
BLj = kaitan ke belakang langsung dan tidak langsung/ direct-indirect backward linkages

$\beta_{\mathrm{j}} \quad=$ indeks daya penyebaran/ backward power of dispersion

$\mathrm{FL}_{\mathrm{i}}=$ kaitan ke depan langsung dan tidak langsung/ direct-indirect forward linkages

$\mathrm{a}_{\mathrm{i}} \quad=$ indeks derajat kepekaan/ forward power of dispersion

$\mathrm{OM}=$ output multiplier atau pengganda output

IM = income multiplier atau pengganda pendapatan

$\mathrm{VM}=$ total value addedmultiplier atau pengganda PDRB

Keterkaitan seluruh sektor ekonomi dalam menggerakkan perekonomian di suatu wilayah sangat diperlukan dalam pengambilan keputusan tentang pengembangan suatu sektor. Sektor dengankaitan langsung ke belakang $\left(\mathrm{B}_{\mathrm{j}}\right)$ tertinggi adalah sektor industri pengolahan nonmigas (0.58) yaitu setiap kenaikan 1 satuan output industri pengolahan nonmigas, nilai sektor yang mendukungnya akan naik 0.58 satuan. Sektor dengan kaitan langsung ke belakang tertinggi berikutnya adalah sektor listrik dan air bersih $(0,44)$ dan sektor komunikasi $(0,43)$. Ketiga sektor ini memiliki nilai $B_{j}^{*}>1$ (tertinggi) yang menunjukkan bahwa sektor ini memiliki pengaruh kuat terhadap pertumbuhan sektor lain dalam memenuhi derived demand (turunan permintaan) yang ditimbulkan oleh sektor ini.

Selain memiliki kaitan langsung ke belakang, ketiga sektor tersebut juga memiliki kaitan ke belakang langsung dan tidak langsung (BLj) tertinggi yaitu sektor industri pengolahan nonmigas sebesar 1.67 (artinya, setiap kenaikan 1 unit permintaan akhir industri pengolahan nonmigas berpengaruh tidak langsung sebesar 1.67 unit terhadap peningkatan total output seluruh sektor ekonomi), sektor listrik dan bersih sebesar 1.65 serta sektor komunikasi sebesar 1.65. Ketiga sektor ini memiliki indeks daya penyebaran $\left(\beta_{\mathrm{j}}>1\right)$ yang tinggi atau memiliki kekuatan relatif dalam permintaan akhir yang mampu mendorong pertumbuhan produksi total seluruh sektor ekonomi.

Kaitan langsung ke depan $\left(\mathrm{F}_{\mathrm{i}}\right)$ tertinggi dimiliki oleh sektor bangunan sebesar 1.10 yang berarti sejumlah 1.10 satuan output sektor bangunan dipakai oleh sektor-sektor lainnya. Sektor dengan kaitan langsung ke depan tertinggi berikutnya adalah sektor tanaman bahan makanan $(0,84)$ dan sektor perdagangan $(0,58)$. Nilai $F_{i}^{*}(>1)$ dari sektor bangunan sebesar 3.91 menunjukkan bahwa sektor ini memiliki pengaruh kuat dalam menghasilkan output untuk input sektor-sektor lain. Nilai $\mathrm{F}_{\mathrm{i}}^{*}$ sektor tanaman bahan makanan dan sektor perdagangan sebesar 2.97 dan 2.07. Output dari sektor-sektor yang memiliki nilai $\mathrm{F}_{\mathrm{i}}{ }^{*}<1$ lebih banyak digunakan untuk memenuhi konsumsi akhir.

Sektor bangunan juga memiliki kaitan ke depan langsung dan tidak langsung (FLi) tertinggi sebesar 2.42 yang berarti jika permintaan akhir tiap sektor perekonomian meningkat 1 satuan maka sektor bangunan menyumbang pemenuhannya sebesar 2.42 satuan. Begitu pula untuk sektor tanaman bahan makanan (2.13) dan sektor perdagangan (1.86). Ketiga sektor ini memiliki indeks derajat kepekaan $\left(\alpha_{i}\right)$ paling tinggi yaitu secara strategis mampu memenuhi permintaan akhir di atas kemampuan rata-rata.

Selain keterkaitan antarsektor, terdapat pula efek pengganda (multiplier effect) yang merupakan suatu dampak yang terjadi baik secara langsung maupun tidak langsung terhadap berbagai kegiatan ekonomi domestik sebagai akibat adanya perubahan pada variabel-variabel eksogen perekonomian.Melalui pengamatan ini, perencana pembangunan nantinya bisa menetapkan target-target pembangunan ekonomi daerah dan kebutuhan dana pembangunan sektoral. Efek pengganda yang dikaji terdiri atas 3 (Rustiadi 2011) yaitu 1) pengganda output (output multiplier) merupakan dampak meningkatnya permintaan akhir suatu sektor terhadap total output seluruh sektor; 2) pengganda pendapatan (income multiplier) merupakan dampak meningkatnya permintaan akhir suatu sektor terhadap peningkatan pendapatan rumah tangga; 3) pegganda PDRB (total value added multiplier)merupakan dampak meningkatnya permintaan akhir suatu sektor terhadap peningkatan PDRB.

Tiga sektor dengan penggandaoutputtertinggi adalah sektor komunikasi (382.48), sektor perhotelan (105.04) dan sektor restoran $(101,49)$. Nilai penggandaoutput sektor komunikasi 
sebesar 382.48 menunjukkan bila permintaan akhir sektor komunikasi meningkat 1 satuan maka total output akan meningkat 382.48 satuan. Adapun tiga sektor yang memiliki pengganda pendapatan tertinggi yaitu sektor industri pengolahan nonmigas (10.07), sektor listrik dan air bersih (9.79) serta sektor pengangkutan (9.37). Sektor industri pengolahan nonmigas memiliki nilai income multiplier tertinggi sebesar 10.07 yang berarti bila permintaan akhir sektor industri pengolahan nonmigas meningkat 1 satuan maka pendapatan rumah tangga akan meningkat 10.07 satuan. Selain itu, tiga sektor yang memiliki pengganda PDRB tertinggi adalah sektor industri pengolahan nonmigas (2.89), sektor restoran (2.48) dan sektor perhotelan (2.13). Efek pengganda sektor industri pengolahan nonmigas sebesar 2.89 berarti bila permintaan akhir sektor industri pengolahan nonmigas meningkat 1 satuan maka PDRB akan meningkat 2.89 satuan.

Berdasarkan hasil analisis sektor unggulan di Kabupaten Manggarai Timur, tiga sektor yang terindikasi berpeluang dalam memimpin dan menggerakkan roda perekonomian (leading sector) di Kabupaten Manggarai Timur adalah sektor tanaman bahan makanan, sektor industri pengolahan nonmigas dan sektor perdagangan. Ketiga sektor tersebut memiliki ciri-ciri sektor unggulan atau sektor pemimpin/leading sector (Arsyad 1999) yaitu 1) perkembangannya relatif cepat; 2) industrinya relatif besar untuk memberikan dampak langsung dan tidak langsung; 3) memiliki keterkaitan tinggi antar industri dan 4) inovatif. Sektor ini juga dianggap memiliki daya sebar dan kepekaan yang sangat tinggi dalam suatu perekonomian, sehingga efeknya bersifat ganda. Ketiga sektor ini harus dikembangkan secara optimal di Kabupaten Manggarai Timur karena paling efektif dalam menggerakkan perekonomian daerah secara berkesinambungan. Untuk itu perlu perhatian serius dari pemerintah agar menetapkan kebijakan-kebijakan yang kondusif untuk pengembangan ketiga sektor ini.

Dalam pengembangan sektor tanaman bahan makanan harus diperhatikan jenis komoditi yang sesuai dengan kondisi daerah baik aspek lahan maupun kontinuitas hasil produksi, sehingga dapat ditetapkan menjadi komoditi unggulan daerah. Berdasarkan hasil analisis komoditi unggulan, beberapa komoditi bahan makanan yang unggul dan layak untuk dikembangkan di wilayah Kabupaten Manggarai Timur sebagai berikut.

1. Kecamatan Borong: padi sawah, jagung, kacang tanah, kakao.

2. Kecamatan Kota Komba: jagung, kacang hijau, kacang tanah, kelapa, kakao, cengkeh, jambu mete.

3. Kecamatan Elar: padi ladang, ubi jalar, kopi robusta, cengkeh, jambu mete.

4. Kecamatan Sambi Rampas: jagung, kopi robusta, kelapa, cengkeh, jambu mete.

5. Kecamatan Lamba Leda: padi ladang, kemiri, jambu mete.

6. Poco Ranaka: padi sawah, ubi jalar, kopi arabika, vanili.

Pengelolaan sektor tanaman bahan makanan di Kabupaten Manggarai Timur selama ini kurang memperhatikan aspek nilai tambah yang dapat meningkatkan daya saing komoditi daerah. Oleh sebab itu dalam pengembangannya, perlu diperhatikan keterkaitan antara sektor tanaman bahan makanan dengan sektor industri pengolahan untuk peningkatan nilai tambah dan sektor perdagangan untuk pendistribusian hasil produksi. Dalam pengembangan sektor industri pengolahan, pemerintah perlu menetapkan iklim usaha yang kondusif bagi pertumbuhan industri kecil dan menengah yang jumlahnya cukup banyak di Kabupaten Manggarai Timur, terutama yang berkaitan dengan pengolahan hasil pertanian.

Semakin ketatnya persaingan bisnis memacu dunia usaha untuk selalu mencari keunggulan kompetitif maupun komparatif berdasarkan nilai tambah yang diciptakan. Pertumbuhan industri penghasil nilai tambah dengan berbasiskan pada potensi lokal merupakan strategi jitu untuk menggerakkan ekonomi daerah berdasarkan potensi yang dimilikinya. Nilai tambah yang didapat inilah yang diharapkan dapat menumbuhkan lapangan kerja dan meningkatkan pendapatan masyarakat setempat. Dalam pengembangan sektor perdagangan, pemerintah daerah perlu memperhatikan para pedagang kecil yang berusaha di wilayah Kabupaten Manggarai Timur agar tidak tersingkir oleh aktifitas perdagangan berskala besar terutama investor dari luar daerah. 


\section{Tutupan/Penggunaan dan Kemampuan Lahan Kabupaten Manggarai Timur}

Tutupan/penggunaan lahan di Kabupaten Manggarai Timur diklasifikasikan dalam 8 kategori yaitu hutan, hutan bakau, kebun campuran, padang rumput, semak belukar, tanah rawa, pemukiman dan tanah ladang. Berdasarkan hasil analisis, tutupan/penggunaan lahan terbanyak di Kabupaten Manggarai Timur adalah semak belukar seluas 133.834,47 Ha (54.62 \%).

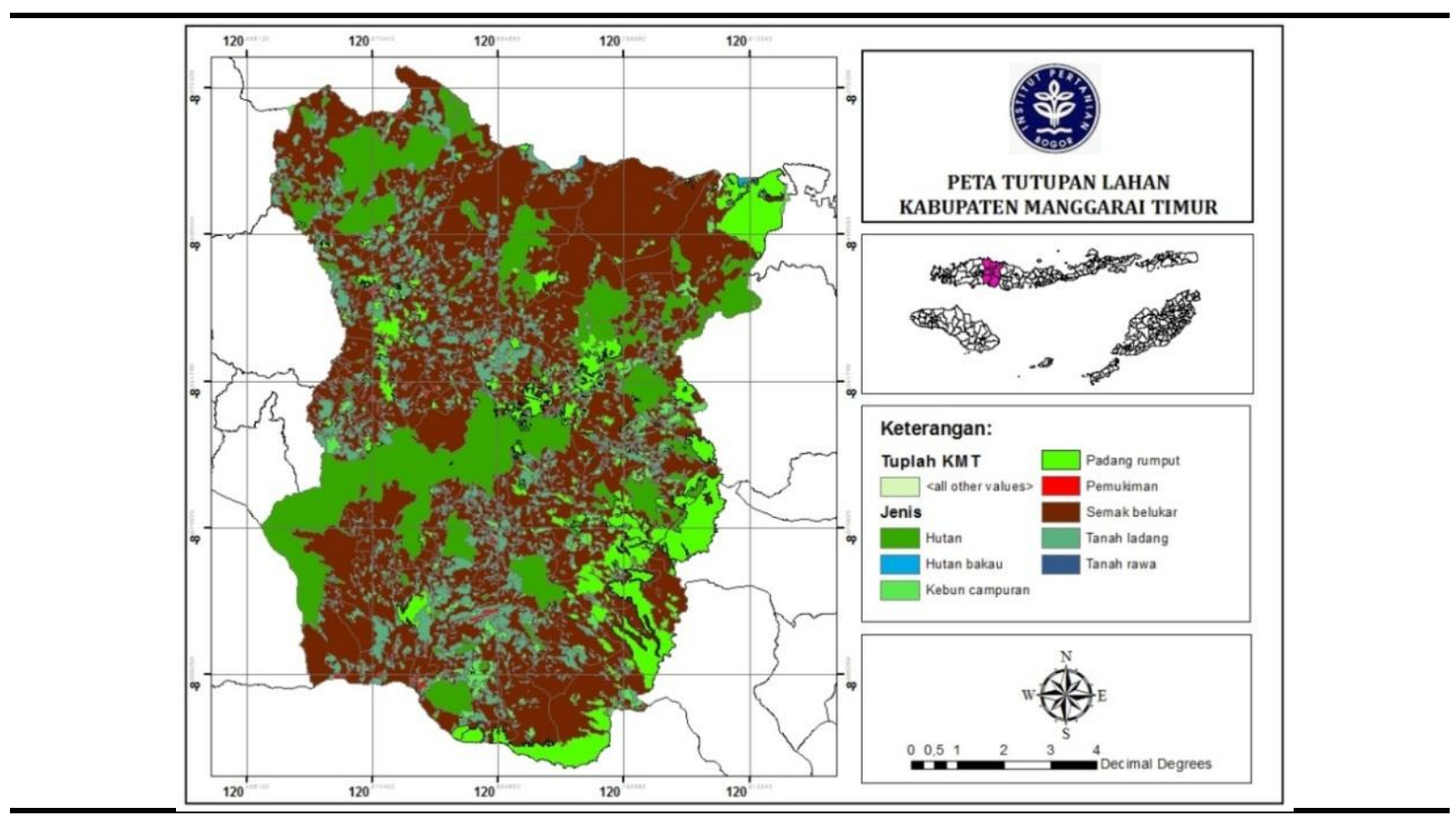

Gambar 3. Peta Tutupan/Penggunaan Lahan Kabupaten Manggarai Timur

Klasifikasi kemampuan lahan dilakukan dengan metode faktor penghambat yaitu setiap kualitas lahan atau sifat-sifat lahan diurutkan dari yang terbaik sampai yang terburuk atau dari yang paling kecil sampai yang paling besar hambatannya. Semakin kecil hambatannya, semakin baik kualitas lahannya atau sebaliknya. Lahan dikelompokan dalam delapan kelas yaitu kelas IVIII. Ancaman kerusakan atau hambatan meningkat berturut-turut dari kelas I sampai kelas VIII (Arsyad 2006). Berdasarkan hasil analisis, Kabupaten Manggarai Timur memiliki 6 kelas kemampuan lahan yang dimulai dari kelas III hingga kelas VIII, sedangkan kelas I dan II tidak terdapat di wilayah ini. Kelas kemampuan lahan yang terdapat di Kabupaten Manggarai Timur dijelaskan sebagai berikut.

1. Kelas kemampuan lahan III

Pada kelas kemampuan lahan III, terdapat tutupan/penggunaan lahan hutan, kebun campuran, padang rumput, semak belukar, tanah ladang dan pemukiman. Tanah-tanah dalam kelas III mempunyai hambatan cukup berat yang mengurangi pilihan pengunaan atau memerlukan tindakan konservasi khusus maupun keduanya. Adapun pembatas pada kelas lahan III yaitu terdapat pada lereng yang landai dengan kemiringan 3 - $8 \%$, kandungan batuan sekitar $15-50 \%$ (sedang), pengolahan tanah agak sulit dan pertumbuhan tanaman agak terganggu. Kelas kemampuan lahan III sangat cocok untuk pertanian tanaman semusim, padang penggembalaan, hutan produksi, hutan lindung dan suaka margasatwa. Penggunaan lahan untuk pertanian memerlukan drainase dan pengelolaan tanah yang dapat memelihara serta memperbaiki struktur tanah. 
2. Kelas kemampuan lahan IV

Pada kelas kemampuan lahan IV, terdapat tutupan/penggunaan lahanhutan, hutan bakau, kebun campuran, padang rumput, pemukiman, semak belukar, tanah ladang, tanah rawa. Adapun pembatas pada kelas lahan IV yaitu terdapat pada lereng yang berbukit dengan kemiringan 15 - $30 \%$, drainase tanah buruk, terutama pada lapisan atas tanah dekat permukaan sering terdapat bercak berwarna kelabu, coklat dan kekuningan. Pada umumnya lahan kelas IV hanya cocok untuk dua atau tiga macam tanaman pertanian atau tanaman dengan produksi yang rendah. Jika digunakan untuk pertanian tanaman semusim diperlukan pengelolaan yang lebih hati-hati dan tindakan konservasi yang lebih sulit diterapkan dan dipelihara, seperti pembuatan terasering, saluran bervegetasi dan dam/bendungan penghambat, di samping tindakan yang dilakukan untuk memelihara kesuburan dan kondisi fisik tanah.

3. Kelas kemampuan lahan $\mathrm{V}$

Pada kelas kemampuan lahan V, terdapat tutupan/penggunaan lahan hutan bakau, padang rumput dan tanah ladang. Adapun pembatas pada kelas lahan $\mathrm{V}$ yaitu kondisi drainase tanah sangat buruk yaitu seluruh lapisan sampai permukaan tanah berwarna kelabu dan tanah lapisan bawah berwarna kelabu serta terdapat air yang menggenang di permukaan tanah dalam waktu yang lama sehingga menghambat pertumbuhan tanaman. Pada umumnya lahan kelas $\mathrm{V}$ hanya cocok untuk padang rumput, padang penggembalaan, hutan produksi atau suaka alam. Pengolahan tanah pada lahan ini biasanya menyulitkan bagi pertanian tanaman semusim, sehingga lebih cocok untuk ditanami rumput atau tanaman pohon dengan pengelolaan yang tepat.

4. Kelas kemampuan lahan VI

Pada kelas kemampuan lahan VI, terdapat tutupan/penggunaan lahan hutan, hutan bakau, kebun campuran, padang rumput, pemukiman, semak belukar dan tanah ladang. Pembatas pada kelas lahan ini yaitu terdapat pada lereng berbukit dengan kemiringan $15-30 \%$ serta kedalaman tanah sangat dangkal. Lahan kelas VI ini lebih cocok digunakan untuk padang rumput, padang penggembalaan, hutan produksi, hutan lindung atau cagar alam. Jika digunakan untuk penggembalaan dan hutan produksi harus dikelola dengan baik untuk menghindari terjadinya erosi. Tanah-tanah dalam lahan kelas VI mempunyai hambatan yang berat sehingga menyebabkan tanah-tanah ini tidak sesuai untuk pengunaan pertanian.

5. Kelas kemampuan lahan VII

Kelas kemampuan lahan VII paling banyak terdapat di Kabupaten Manggarai Timur. Pada kelas kemampuan lahan VII, terdapat tutupan/penggunaan lahan hutan, kebun campuran, padang rumput, pemukiman, semak belukar, tanah ladang dan tanah rawa. Pembatas pada kelas lahan ini yaitu terdapat pada lereng yang curam dengan kemiringan $45-65 \%$. Penggunaan lahan pada kelas lahan VII ini juga sangat terbatas karena hanya cocok untuk padang rumput, hutan produksi dan suaka alam, namun harus dilakukan usaha pencegahan erosi yang berat. Lahan kelas VII tidak sesuai untuk budidaya pertanian. Tanah-tanah dalam lahan kelas VII yang dalam dan tidak peka erosi jika digunakan untuk tanaman pertanian harus dibuat teras bangku yang ditunjang dengan cara-cara vegetatif untuk konservasi tanah, di samping pemupukan.

6. Kelas kemampuan lahan VIII

Pada kelas kemampuan lahan VIII, terdapat tutupan/penggunaan lahan hutan bakau, kebun campuran, padang rumput, pemukiman, semak belukar dan tanah ladang. Adapun pembatas yang terdapat pada kelas lahan VIII ini yaitu kondisi drainase tanah yang berlebihan (excessively drained) yaitu kemampuan tanah untuk menahan air sangat rendah sehingga tanaman akan segera mengalami kekurangan air. Penggunaan lahan pada kelas kemampuan lahan VIII ini paling terbatas dibandingkan kelas lahan lainnya karena sebenarnya hanya cocok digunakan untuk pariwisata dan suaka alam. Lahan kelas VIII merupakan tanah-tanah yang telah rusak atau sangat terdegradasi (badland), tanah-tanah dengan singkapan batuan, 
tempat pembuangan sisa-sisa bahan tambang dan lahan-lahan hampir gundul lainnya. Kelas lahan ini sangat tidak sesuai untuk budidaya pertanian karena seharusnya dibiarkan dalam keadaan alami.

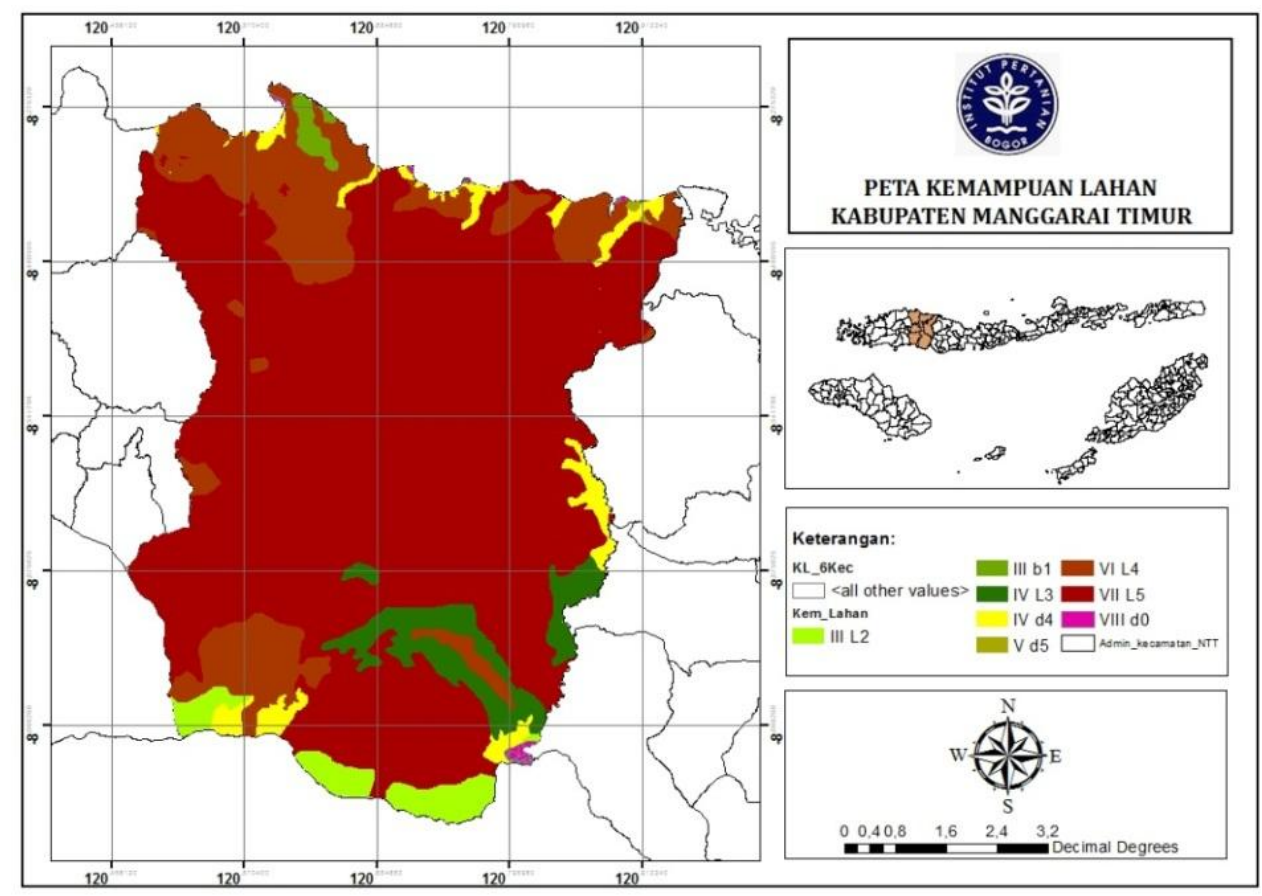

Gambar 4. Peta Kemampuan Lahan Kabupaten Manggarai Timur

Penggunaan lahan yang terdapat di Kabupaten Manggarai Timur, masih banyak yang tidak sesuai dengan peruntukannya. Kondisi yang nyata memperlihatkan masih banyak usahatani yang dikelola di kelas kemampuan lahan ekstrim yaitu kelas V hingga kelas VIII. Padahal usahatani yang memberikan produktifitas hasil baik seharusnya hanya diusahakan pada kelas kemampuan lahan I hingga IV. Dalam pengembangan wilayah, perlu terlebih dahulu dilakukan perencanaan penggunaan lahan yang strategis guna memberikan keuntungan ekonomi bagi wilayah. Perencanaan penggunaan lahan yang strategis bagi pembangunan merupakan salah satu upaya dalam mengoptimalkan pemanfaatan sumberdaya lahan (Sitorus 2004).

\section{Strategi Pengembangan Wilayah}

Berdasarkan hasil analisis berbagai aspek di atas, perlu dirumuskan strategi yang tepat dalam kaitan dengan pengembangan wilayah Kabupaten Manggarai Timur.

1.Pemberdayaan masyarakat secara partisipatif dengan memperhatikan pengetahuan dan kearifan lokal dalam perencanaan pembangunan

2. Pengembangan teknologi yang sederhana dan berbasis pada indigenous knowledge, tepat guna dan padat karya dengan menggunakan potensi/sumberdaya lokal

3. Peningkatan ekonomi masyarakat dengan menggerakkan koperasi danlembaga ekonomi lainnya sebagai wahana perekonomian masyarakat

4. Intensifikasi usaha pertanian untuk meningkatkan kuantitas dan kualitas hasil produksi serta peningkatan optimasi pemanfaatan sumber daya alam dengan penataan kelembagaan pertanian yang kondusif 
5. Peningkatan keterpaduan kegiatan antarsektor yang diwujudkan dalam perencanaan, pembinaan, pelatihan dan evaluasi setiap program/kebijakan

6. Pemanfaatan teknologi pengolahan hasil pertanian untuk pengembangan proses pengolahan pangan lokal yang dapat meningkatkan mutu dan keragaman produk olahan pangan lokal yang dapat memberikan nilai tambah ekonomi

7. Peningkatkansistem kerjasama dan koordinasi antarinstansi untuk mendukung kelancaran pelaksanaan pembangunan dalam rangka melaksanakan otonomi daerah

8. Penataan sistem tata ruang wilayah secara optimal dalam Rencana Tata Ruang Wilayah

Tabel 6 SWOT Pengembangan Wilayah

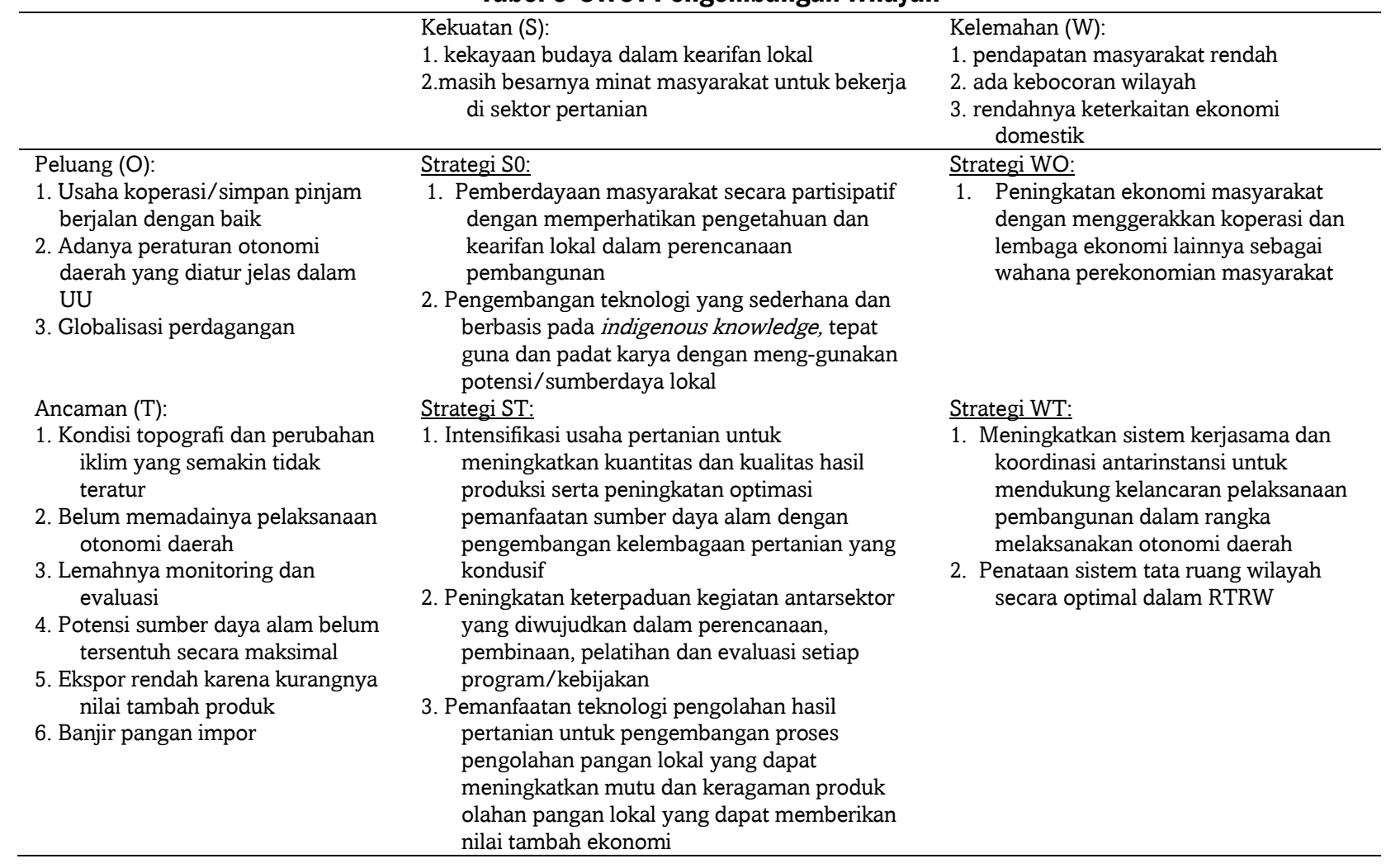

Sumber: Hasil Analisis SWOT 2014

\section{Kesimpulan}

Dari urain di atas dapat disimpulkan beberapa hal sebagai berikut.

1. Sektor unggulan yang mampu meningkatkan perekonomian daerah Kabupaten Manggarai Timur adalah sektor pertanian tanaman bahan makanan, sektor industri pengolahan nonmigas dan sektor perdagangan. Dalam mengefektifkan pembangunan daerah dengan membiayai pembangunan daerah secara mandiri, perlu diperhatikan keterkaitan antar ketiga sektor ini dengan sektor-sektor lainnya agar tercipta keterkaitan sektoral.

2. Tutupan/penggunaan lahan terbesar di Kabupaten Manggarai Timur yaitu semak belukar, sehingga masih banyak peluang bagi pembangunan daerah Kabupaten Manggarai Timur. Adapun sebagian besar penggunaan lahan di wilayah ini tidak sesuai dengan peruntukannya terutama pertanian sehingga perlu diperhatikan dalam pemetaan RTRW.

3. Sebagai daerah otonomi baru, Kabupaten Manggarai Timur masih memiliki banyak peluang untuk dikembangkan. Hal ini tergantung dari niat bersama Pemerintah dan seluruh elemen masyarakat dalam pembangunan dan pengembangan wilayahnya. Untuk itu, Pemerintah 
daerah perlu menetapkan strategi tepat dalam pengelolaan wilayah agar tercipta kesejahteraan mayarakat yang merata di daerah ini.

\section{Saran}

Dengan mengacu pada simpulan di atas, dapat diajukan saran-saran sebagai berikut.

1. Pemerintah perlu meningkatkan keterkaitan antarsektor perekonomian di Kabupaten Manggarai Timur dengan pelaksanaan monitoring dan evaluasi secara berkala

2. Perlu partisipasi aktif dari seluruh elemen masyarakat sebagai pelaku utama dalam pembangunan dan pengembangan wilayah Kabupaten Manggarai Timur

3. Perlu melakukan penelitian lanjutan untuk melihat kesesuaian lahan terhadap setiap komoditi unggulan di Kabupaten Manggarai Timur

\section{Daftar Pustaka}

Ambardi U, Prihawantoro S. 2002. Pengembangan Wilayah dan Otonomi Daerah, Kajian Konsep dan Pengembangan. Jakarta (ID): P2KTPW-BPPT.

1999. Teknik Penyusunan Tabel Input-Output. Badan Pusat Statistik. Jakarta.

[BPS Manggarai Timur] Badan Pusat Statistik Kabupaten Manggarai Timur. 2010. Manggarai Timur dalam Angka. Manggarai Timur (ID): BPS Manggarai Timur.

[BPS Manggarai Timur] Badan Pusat Statistik Kabupaten Manggarai Timur. 2012. Manggarai Timur dalam Angka. Manggarai Timur (ID): BPS Manggarai Timur.

Djakapermana RD. 2010. Pengembangan Wilayah Melalui Pendekatan Kesisteman. Bogor (ID): IPB Press.

Pemerintah Republik Indonesia. 2004. Undang-Undang Republik Indonesia Nomor 32 Tahun 2004 Tentang Pemerintahan Daerah. Jakarta (ID): Sekretariat Negara.

Pemerintah Republik Indonesia. 2007. Undang-Undang Republik Indonesia Nomor 36 Tahun 2007 Tentang Pembentukan Kabupaten Manggarai Timur di Provinsi Nusa Tenggara Timur. Jakarta (ID): Sekretariat Negara.

Priyarsono DS. 2011. Dari Pertanian ke Industri, Analisis Pembangunan dalam Perspektif Ekonomi Regional. IPB Press. Bogor.

Rangkuti F. 2001. Analisis SWOT Teknik Membedah Kasus Bisnis. Jakarta (ID): Gramedia Pustaka Utama.

Rustiadi E, Saefulhakim S, Panuju DR. 2009. Perencanaan dan Pengembangan Wilayah. Ed ke-2. Jakarta (ID). Crestpent Press dan Yayasan Pustaka Obor Indonesia.

Sitanala Arsyad. 2006. Konservasi Tanah dan Air. Bogor: IPB Press.

Sitorus SRP. 2004. Evaluasi Sumberdaya Lahan. Bandung (ID): Tarsito.

Solahuddin Soleh. 2009. Pembangunan Pertanian Awal Era Reformasi. Jakarta Selatan. PT PP Mardi Mulyo.

Sudantoko HD, Hamdani M. Dasar-Dasar Pengantar Ekonomi Pembangunan. Jakarta (ID): PP Mardi Mulyo.

Syah Dahrul. 2013. Riset untuk Mendayagunakan Potensi Lokal. Bogor. IPB Press .cetakan kedua

Tarigan R. 2006. Perencanaan Pembangunan Wilayah. Ed Revisi. Jakarta (ID): Bumi Aksara.

Widiatmaka. 2013. Analisis Sumberdaya Lahan untuk Perencanaan Tataguna Lahan dan Wilayah. Departemen Ilmu Tanah dan Sumberdaya Lahan. 